\title{
Candor, Wisdom, and Persistence: The Keys to Stabilizing the All-Important Economic Relationship Between China and the US
}

\author{
Timothy P. Stratford
}

\begin{abstract}
Issues in the US-China trade relationship remain a barrier to truly sustainable and mutually beneficial trade between the two countries. The Phase One agreement between the US and China dealt with some issues, but did not address "interoperability" challenges arising from differences in the two countries' economic systems. National security concerns, especially in telecommunications, are also a sticking point. Lessons learned from Phase One negotiations have resulted in both countries taking measures that reduce mutual reliance, but ultimately should result in a shared goal of seeking "harmony despite differences".
\end{abstract}

Keywords Phase one agreement $\cdot$ National security $\cdot$ Reduced mutual reliance Harmony despite differences

Over the past 38 years, I have devoted my career to promoting sustainable and mutually beneficial trade relations between the US and China, because it seemed to me that getting this relationship right is one of the most consequential tasks and challenges of our time. I have done this as a lawyer, US diplomat, general counsel of a major American company's operations in China, and as three-term chairman of the American Chamber of Commerce in China. As a former US trade negotiator, I salute the extraordinary efforts of our negotiators from both countries today and understand the daunting challenges they face.

In this paper, I would like first to discuss-from an American perspective- the trade policy issues that have negatively impacted this incredibly important relationship, and the extent to which they are addressed in the Phase One agreement concluded between the US and China on January 15, 2020. I would then like to discuss the agreement's place within the context of the overall US-China economic relationship, which is increasingly defined by competition and increasingly inseparable from national security considerations. Finally, I would like to offer some thoughts on lessons learned, as well as on US objectives over the coming months and years and possible approaches for achieving them.

T. P. Stratford $(\varangle)$

Covington \& Burling LLP Beijing Representative Office, Beijing, China

H. Wang and L. Miao (eds.), Transition and Opportunity, China and Globalization, https://doi.org/10.1007/978-981-16-8603-0_3 


\section{Issues in the US-China Trade Relationship}

As I see it, US trade negotiators have thus far confronted three types of issues with China, with the three types listed below in ascending order of difficulty and criticality:

First, there are issues on which China has previously made commitments, either multilaterally or bilaterally, but has not fully delivered on its promises to the reasonable satisfaction of its trading partners. These can be very specific pledges to open a particular sector or change a regulation, or they can be broad statements of principle, such as a commitment to strengthen intellectual property protection or refrain from state interference in commercial transactions. In some cases, the commitment has arguably been implemented only partially; in others, not at all; or in many cases, it has been nominally implemented, but then Chinese officials have taken other actions that have had the effect of denying the intended benefit to China's trading partners.

Second, there are issues on which no commitments have been made but where existing measures and practices clearly stand in the way of fair and reciprocal trade. For example, Chinese companies are able to do business in certain sectors and sell certain products and services in the US market, while American companies are not permitted to do the same for these sectors, products, and services in China. Chinese cloud service providers, for example, can freely operate in the US, but US providers of cloud services cannot have a meaningful commercial presence in China.

Third, there are issues that are systemic and stem from differences between the economic models of China and other countries-differences that create uneven competitive conditions for producers and service providers. When China joined the World Trade Organization, the hope and expectation of China's trading partners was that China would gradually converge with international norms and evolve into a more market-oriented and transparent economy. Although China has opened markets and welcomed foreign investment in a number of sectors, the state's decisive role in certain key sectors such as financial services, telecommunications, energy, and transportation, and its ambitious goals in important high-tech sectors as exemplified in the Made in China 2025 program and more recent initiatives work to advantage Chinese national champions domestically and globally - through subsidization, protectionist industrial policies, and opaque informal measures that defeat the assumption that trade is conducted on the basis of comparative advantage. These issues have intensified in recent years as China has, in various ways, doubled down on this state-led model and strengthened controls over the economy and businesses.

The limitations of the approaches and tools that the US has relied on over the past two decades to address these issues have become increasingly apparent. For an international agreement to be effective and durable, each side must believe that implementation of the agreement is in its own interest, and the agreement must usually establish an effective enforcement mechanism. However, multilateral and bilateral trade agreements and dialogues with China have often produced incremental commitments that China-over time-has not regarded as fully in its interest, and that have not been supported by processes to effectively enforce their implementation. The WTO's disciplines, for example, simply do not speak to many of the most serious 
problems, and the WTO dispute settlement mechanism, while successful in many cases, has often required so much time to complete that the damage was done by the time a final ruling was issued and implemented.

As we know, the Trump Administration took a radically different approach, returning to Sect. 301 of US trade law - a unilateral tool that had been used to address unfair trade practices before the WTO dispute settlement mechanism was established. This led to the imposition by the US of additional tariffs of approximately USD 370 billion on Chinese goods and retaliatory tariffs by China of nearly USD 100 billion on US goods. Eventually, both sides found their way back to the negotiating table, with a sweeping negotiation agenda far broader than the issues covered in the Sect. 301 report-which had focused on technology transfer and cyber-theft of intellectual property. As Ambassador Robert Lighthizer has stated, the Administration was "pressing for significant structural changes that would allow for a more level playing field."

\section{Assessing the Phase One Trade Agreement}

The resulting Phase One agreement secured commitments from China in five areas that were often the subject of past negotiations: intellectual property, technology transfer, agriculture, financial services, and currency. In some cases, these commitments broke new ground and significantly exceeded the results of past negotiations. In other cases, they affirmed, clarified, or expanded somewhat upon existing commitments.

On intellectual property, the agreement includes specific provisions related to trade secrets, patents, online piracy, geographical indicators, bad-faith registration of trademarks, and enforcement. With respect to trade secrets, many of the promised reforms - which could significantly strengthen the protection of this form of IP - had already been codified in recent Chinese legislation. But it is no doubt the case that this legislation was catalyzed in part by the negotiations, as well as by China's own desire to foster innovation and improve its image on IP protection. The agreement breaks the most new ground on patent protection for pharmaceuticals, in some cases reflecting reforms that China had contemplated but until now had not actually adopted. These commitments include provisions for patent term extensions and a mechanism for early resolution of patent disputes.

However, the agreement does not address other areas where US stakeholders in other industries - especially in the Information and Communications Technology (ICT) sector-have had serious concerns, such as China's approach to standard, essential patents, and the impact of Chinese competition law enforcement on licensing agreements and global patent disputes. The agreement builds modestly on existing bilateral commitments in the areas of online piracy and geographical indicators. It also addresses bad-faith registration of trademarks, though it does not commit China to take any specific action in this regard. It commits China to strengthen criminal deterrents to IP theft, reflecting in part new measures that China 
rolled out last year; but it stops short of requiring more fundamental reforms to China's judicial system. With respect to enforcement, the agreement emphasizes onetime "campaign-style" enforcement initiatives against specific types of infringement, though this is a model that has failed in the past to produce lasting change.

Overall, as observed by noted Chinese IP law expert Mark Cohen of the Berkeley Center for Law and Technology: "The reforms in the Agreement...in many cases appear more focused on yesterday's problems. While the continued emphasis on administrative agencies and limited focus on civil remedies is disappointing, there are nonetheless many notable IP reforms in the Agreement in addition to legislative reforms already delivered."

On technology transfer, which occupies a mere two pages of the text, the commitments are on the level of general obligations not to compel the transfer of technology or direct outbound investments to acquire technology. China's government has consistently denied engaging in forced technology transfer, and the agreement does not address the incentives in China's system that create informal pressures on foreign companies to transfer technology. But the general principles, which were also codified last year in China's new foreign investment law, may provide an enforcement hook or a foundation for future negotiations.

On agriculture, the agreement represents significant progress in the form of detailed commitments to remove a long list of specific non-tariff barriers that impede US agriculture, seafood, and biotech exports, while also calling for improved transparency in Chinese regulatory processes. The value of these commitments will depend on whether China introduces new barriers to keep out the same products, and if it does, on whether the enforcement mechanism can effectively address this issue as it arises.

On financial services, the agreement memorializes and modestly expands upon China's recent actions to open its financial sector to greater foreign participation. The main value-adds contributed by the agreement are to commit China to timelines for the approval of licenses and to clarify the permitted scope of business in individual sectors of financial services.

On currency, the agreement breaks almost no new ground, largely reiterating commitments that China has already made in the G-20, the IMF, and bilaterally, such as to refrain from competitive devaluation-which has not been an issue for several years, and to enhance transparency around intervention in foreign exchange markets.

In addition to addressing issues in each of these five areas, the Phase One agreement also includes two novel features that distinguish it from past agreements and are potentially quite impactful - at least in the short run, namely, specific commitments to increase imports from the US, and an agreement to implement a new type of enforcement/dispute resolution mechanism.

On expanding trade, China committed to import an additional USD 200 billion of US goods and services during the 2020-21 time period - beyond what it would have imported if it simply maintained the annual level of imports it achieved in 2017. This commitment arguably presented real sales opportunities for US firms, especially given the specific annual purchase amounts agreed upon for 20 subcategories of 
manufactured goods, agricultural products, energy, and services. But China's shortfall in implementing this commitment, especially given the impact of the Coronavirus outbreak, has been disappointing.

Moreover, there was an inherent tension in this chapter of the agreement between specific purchase commitments and language stating that purchases will be made based on commercial considerations and market conditions. There is also a disconnect between what amounts to managed trade and the emphasis on market-based reform included elsewhere in the agreement. Some commentators have flagged a potential conflict with China's WTO obligations - to the extent that these commitments are deemed as binding restrictions on trade flows. The agreement attempts to address these concerns about possible trade diversion by stressing that reforms undertaken according to the agreement — and the resulting increased trade flows - will expand exports to China from other countries as well as from the US.

The dispute resolution mechanism is unlike that of the WTO and most free trade agreements in that relies not on an independent arbitral body, but instead on the right of the complaining party to impose "a remedial measure in a proportionate way" to address an alleged violation of the agreement-following a process of escalating bilateral consultations. If the responding party believes that the complaining party is acting in bad faith in taking such an enforcement action, its only recourse is to withdraw from the agreement. This right to be "judge, jury, and executioner" could provide swifter and more certain enforcement. But it may also increase the fragility of the agreement.

For example, if China feels the US is acting unfairly in unilaterally enforcing the agreement, it could in retaliation claim US infractions of some kind and impose its own remedial measures. The result could be an unraveling of the Phase One agreement and a return to the retaliatory tariffs and downward spiral in the relationship that the agreement was intended to address. Nevertheless, speaking as a former US trade negotiator, I would have been delighted to have had access to this new dispute resolution process as I worked to remove barriers American companies experienced in China, because in the past—with respect to most issues-we essentially had no enforcement option other than to launch a WTO case.

In summary, on the substantive commitments, the agreement represents new progress primarily in protecting intellectual property-especially for pharmaceuticals, and in addressing long-standing trade barriers to American farm exports. Most of the issues affecting US technology companies-such as digital trade, technology licensing, and cybersecurity regulation-were not addressed, nor were those affecting services other than financial services.

Many of the commitments included in the agreement fall into the first category of issues that I described at the outset and are aimed at reiteration, amplification, and clarification of previous commitments. In addition, a fair number fall into the second category and represent new commitments addressing various discrete trade barriers and specific examples of non-reciprocal treatment. But virtually nothing in the agreement substantially addresses any of the category three "systemic issues," which arise because of differences in the economic models of our two countries. Unfortunately, as noted above, it is the systemic issues that are most critical, as they 
are the ultimate source of the imbalances in our economic relationship and the basis for the perpetuation of an uneven playing field.

\section{Impact of National Security Concerns on the Bilateral Economic Relationship}

One of the reasons these negotiations have failed thus far to address the systemic issues is that national security concerns on both sides have greatly complicated the trade relationship. For the US, national security policies have traditionally had a relatively limited impact on trade policy. But now, both the US and China are justifying a wide range of measures that have enormous impact on trade and investment in the name of national security. This is in large measure due to technological change, where ubiquitous and rapidly evolving consumer technologies such as those found on our mobile devices — and the use of big data associated with them - may also have advanced military applications or create sobering national security vulnerabilities.

Moreover, China's aggressive pursuit of its Made in China 2025 strategy and other similar industrial policy goals have heightened concerns in the US, Europe, and elsewhere that China is exploiting differences in our economic systems to advance its own system and strategic interests at others' expense. These concerns are amplified by the growing strategic competition between the US and China. As the race for technological superiority between our two countries intensifies, and each country takes steps to protect its national security that grant advantages to its own companies, each side is growing increasingly wary of the intentions of the other regarding the future of bilateral economic relations. Concern is growing in the United States that China's ambitious industrial and technology acquisition policies are aimed at achieving military and geostrategic dominance. And China seems increasingly convinced that the intention of the US-including through the instrumentality of the trade negotiations - is to impede China's technological development and ultimately to undermine the rule of the Communist Party.

Under these circumstances, it is likely that China will resist more strongly than ever US pressure to reduce industrial policy support for domestic high-tech industries or to open its markets further to the US-especially when it believes that it could be hit at any time by new tariffs or sanctions that make reliance on US goods, services, and technologies a vulnerability. It is therefore hard to see how our two countries will be able to address the systemic trade issues unless a broad and shared understanding is reached regarding which technologies each country must control, which data flows they should restrict, and which supply chains and infrastructure they must protect on national security grounds. 


\section{Lessons Learned from the Phase One Trade Negotiations}

Looking ahead, we can be sure that future developments in US-China economic relations, in the economic development policies of each of our two countries, in the business plans and activities of individual American and Chinese businesses, and in the economic policies and strategies of governments and companies in other countries-will all be profoundly impacted by what we each have learned in the course of the Phase One trade negotiations and the trade war that accompanied them. And what exactly have we learned?

Perhaps most significantly, the Chinese government has almost certainly concluded that - from its perspective - the US is not as "reliable" a trading partner as previously assumed. The importance of this new assessment cannot be overstated. For the first time since China joined the WTO two decades ago, the US has demonstrated a willingness to impose substantial tariffs on a vast array of Chinese goods and to significantly tighten restrictions on Chinese businesses' access to various US technologies and high-tech components-either to increase US leverage in the trade negotiations or to address national security concerns.

As a result, the Government of China-as expected-is rapidly accelerating its efforts to become self-sufficient in key technologies, components, and commodities, in order to reduce future vulnerability to US pressure. This is particularly evident with respect to elements of its economy that it regards as "critical infrastructure." This means that in these particular sectors, opportunities for US companies to participate in the hugely important China market are diminishing in significant ways, and the Chinese government is strongly incentivized to increase its industrial policy support for Chinese companies rather than engage in the types of systemic reforms sought by the US. It also means that addressing these systemic issues in "Phase Two" negotiations will be extremely difficult, and that the Chinese government will likely want to maintain the current fragile truce and draw out the negotiation process as long as possible in order to extend the time period it has to prepare for the next time the US decides to impose tariffs or other sanctions.

The US government has learned that the imposition of tariffs can certainly help bring Chinese officials to the negotiating table, but that tariffs alone are not enoughat least at present - to persuade the Chinese government to make commitments it believes are not in its own interest, especially when such commitments would require significant changes to its existing economic model. The US government has also come to better understand the near-term cost and disruptive impact on American businesses, on American competitiveness and innovation, and on the US and global economies that can result from raising tariffs and applying additional restrictions on bilateral economic cooperation. However, as discussed below, the full cost and disruptive impact of engaging in this tariff war have only just begun to be felt; the full extent of the long-term impact will depend on how wisely China and the US manage the next stage of this relationship.

American companies have learned that their businesses cannot rely as fully as in the past on suppliers or customers in China-and the same is true for Chinese 
companies relying on Americans_-because of the risk that new tariffs or trade and investment restrictions may be applied by one or both of the two governments. Again, the importance of this development cannot be overstated, though it is taking time for the full implications to become evident, and the impact is being felt in some sectors much more heavily than in others. Depending on the sectors in which they operate and the primary markets in which they wish to sell, American companies must often now adopt either an "in China for China" strategy, or a "China plus one" strategy.

Under the first, American and other foreign companies seek to meet Chinese industrial policy and national security requirements by working with local partners to design and manufacture products (or provide services) in China for the China market. This strategy is most likely to be attractive to companies that prioritize the China market. It is most likely to be accepted by Chinese regulators (a) so long as pure domestic companies are unable to provide equivalent products and services of adequate quality, or (b) after domestic Chinese companies have already established market dominance in the particular sector.

Under the "China plus one" approach, American companies that look to China for inputs seek to supplement their existing Chinese suppliers with suppliers outside of China, and American companies that have relied critically on China as a market, seek to develop other markets - in both cases to help mitigate the risk that trade flows between the US and China may experience further disruption. Indeed, no matter what country you hail from, if a new factory needs to be constructed or a new supplier brought on line, and if you hope to sell into the two largest markets in the worldnamely, the US and China-then the safest bet is to invest in a location other than one of these two countries, to avoid the risk that one of them may restrict trade flows from the other.

\section{Achieving a New Equilibrium in US-China Economic Relations}

Most Americans doing business with China understand the imperative each country feels to safeguard its national security and foster its own economic and technological development, and most acknowledge that circumstances have changed over the past 20 years, requiring a major recalibration of the US-China economic relationship. As this recalibration unfolds, many are making adjustments to their business strategies and plans. However, we should not accept the simplistic and largely unexamined view, embraced by some in each country, that their side will ultimately be better off-both economically and from a national security perspective-if the two economies are "decoupled."

Indeed, we should be especially concerned if such decoupling proceeds largely unguided and unbounded as a result of conflicting policy signals emanating from Washington and Beijing. We should remember that despite the challenges we face, both countries have benefited enormously from our bilateral economic engagement, 
from China's development over the past two decades, and from the relatively positive relations between our two countries that have accompanied these developments. Given the complexity of existing supply chains, the revenues our high-tech companies have received from China that have largely funded their ongoing R\&D efforts, and our own vulnerabilities if these supply chains are disrupted, Americans should only contemplate decoupling if it would involve critically sensitive technologies that are narrowly defined - and if the feasibility of a specific decoupling measure has been confirmed on the basis of a careful cost/benefit analysis. The American and Chinese people will both benefit greatly if we limit the negative impact of national security measures on our economies by erecting "high walls around small spaces," and by providing more predictability for businesses.

With respect to the systemic trade policy issues, it appears that a new approach is required. In the past, US-China relations were guided largely by a shared interest in helping China “align with the world” (与世界接轨), i.e., to participate in and conform to a world order that frankly was largely established and has largely been led by the United States. China's accession to the WTO after a very lengthy negotiation period was a major milestone in this process, and since that time, US trade negotiations with China have generally focused on China's often imperfect compliance with the US view of how WTO members should regulate their economies.

However, in the course of the Trump-era negotiations and in the face of substantial pressure from the United States, the Chinese government evidently decided to reject more explicitly and forcefully than before the US view of how economies and economic relations with other countries should be regulated. China wishes to be seen as a champion of "globalization," but its interpretation of "globalization" is a kind of "globalization with Chinese characteristics" that comfortably accommodates China's own economic model and political system.

For this reason, since China is not likely, within the short-to-mid-term, to make further meaningful changes to its system, it makes sense, in future US-China negotiations, to adopt a new paradigm. Rather than focusing on (and arguing about) China's level of conformity with the existing world order, this new paradigm would focus instead on "interoperability," i.e. explicitly acknowledging China's different approaches and — to use a Chinese phrase—seek “harmony despite differences” (和 而不同). Such an approach could be implemented in a way that respects China's sovereignty, and at the same time, it could result in a more proactive and clear-eyed response to the challenges presented by China's economic development model. This approach could include:

1. The two countries objectively and forthrightly listing differences between our two systems and identifying those differences and practices that result in unfair advantages for one side or the other;

2. Allowing each country to explain in reasonable terms the nature of the harms it is suffering, and to quantify the harms-if possible; and

3. Inviting the country whose system and practices cause the harm to propose ways to mitigate it, while understanding that if the harm cannot be addressed through 
such mitigation, the country suffering the harm may take reasonable, measured actions to address it on its own.

Of course, before deciding how to address the harm, the harmed country will need to identify remedial actions that don't themselves cause greater harm to its own interests than the original harm being suffered. The other country can then judge whether the actions taken are reasonable under the circumstances. In addition, the harmed country should take care not to overstate the negative consequences of the other country's actions, recognizing that the harmed country's own policies within its own borders may ultimately matter more than the policies of the other country.

Such an approach would require high-level negotiations between the US and China where the negotiators on each side would be empowered to address a broad array of bilateral issues. It would also require a level of candor, wisdom, and persistence that neither country has fully demonstrated in its dealings with the other. During the height of the Cold War, American and Soviet negotiators were able to develop shared language and analyses that allowed them to manage the risks inherent in their large nuclear arsenals. Today we face challenges with China on economic issues, national security issues, and issues that lie between.

When candor is not forthcoming by one side regarding its policies or practices that may be harmful to the economic interests of the other side, the complaining side could transparently announce, justify, and apply adverse inferences and reasonable mitigation measures. Hopefully through this process, the level of trust and predictability in the bilateral economic relationship would rise as each side sees the value of transparency in its economic policies and practices and the importance of reasonable proportionality in its responses to the harmful conduct of the other side.

On the US side, working through all of these issues will require close coordination and communication-between the legislative and executive branches of the government and also between the government and the private sector. We are entering uncharted waters, as there is no modern precedent for two countries to be at the same time each other's main economic partner and major military and geopolitical rival.

At the same time, the US will need to work much more closely and actively with Europe, the UK, Japan, Australia, India, South Korea, and other nations as well as international bodies to develop constructive multilateral and plurilateral responses to shared concerns about China's policies and practices. And most importantly, the US government and private sector will need to focus more on their own path for future economic and technological development-to ensure long-term success in competing with China and other powers.

Addressing each of these challenges will require exceptional creativity and foresight. But few undertakings will affect so profoundly our own national interests and the well-being of so many people as this one. The bilateral economic relationship has served as the ballast for the overall relationship between the US and China since the normalization of diplomatic relations in 1979. We cannot afford to ignore or mismanage this important stabilizing influence and driver of economic benefits and goodwill. 


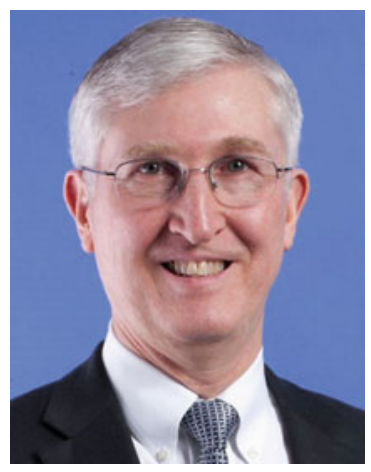

Timothy P. Stratford is managing partner in Covington \& Burling LLP's Beijing office. As a former assistant at United States Trade Representative (USTR), Mr. Stratford is the most senior former US official working as a member of the US business community in China. Except for the five years he spent in Washington at USTR (2005 to 2010), Mr. Stratford has lived and worked continuously in the greater China region since 1982, including as minister-counselor for Commercial Affairs at the US Embassy in Beijing and as general counsel for a major US company's China operations. He has also served three terms as Chairman of the American Chamber of Commerce in China. Mr. Stratford is a graduate of Brigham Young University and Harvard Law School.

Open Access This chapter is licensed under the terms of the Creative Commons AttributionNonCommercial-NoDerivatives 4.0 International License (http://creativecommons.org/licenses/bync-nd/4.0/), which permits any noncommercial use, sharing, distribution and reproduction in any medium or format, as long as you give appropriate credit to the original author(s) and the source, provide a link to the Creative Commons license and indicate if you modified the licensed material. You do not have permission under this license to share adapted material derived from this chapter or parts of it.

The images or other third party material in this chapter are included in the chapter's Creative Commons license, unless indicated otherwise in a credit line to the material. If material is not included in the chapter's Creative Commons license and your intended use is not permitted by statutory regulation or exceeds the permitted use, you will need to obtain permission directly from the copyright holder.

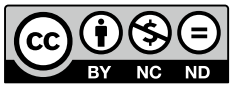

